\title{
Investigation of interior post-insulated masonry walls with wooden beam ends
}

\author{
Morelli, Martin; Svendsen, Svend
}

Published in:

Journal of Building Physics

Link to article, DOI:

10.1177/1744259112447928

Publication date:

2013

Document Version

Early version, also known as pre-print

Link back to DTU Orbit

Citation $(A P A)$ :

Morelli, M., \& Svendsen, S. (2013). Investigation of interior post-insulated masonry walls with wooden beam ends. Journal of Building Physics, 36(3), 265-293. https://doi.org/10.1177/1744259112447928

\section{General rights}

Copyright and moral rights for the publications made accessible in the public portal are retained by the authors and/or other copyright owners and it is a condition of accessing publications that users recognise and abide by the legal requirements associated with these rights.

- Users may download and print one copy of any publication from the public portal for the purpose of private study or research.

- You may not further distribute the material or use it for any profit-making activity or commercial gain

- You may freely distribute the URL identifying the publication in the public portal

If you believe that this document breaches copyright please contact us providing details, and we will remove access to the work immediately and investigate your claim. 


\title{
SUBMITTED VERSION 1 - BEFORE PEER-REVIEW
}

\section{MAJOR CHANGES WERE MADE TO THE FINAL VERSION OF THE PAPER}

\section{COVER PAGE}

Paper title: Method for Investigation of Interior Post-Insulated Masonry Walls with Wooden Beam Ends

\author{
Authors: \\ Martin Morelli (corresponding author*) \\ $\mathrm{PhD}$ student \\ Department of Civil Engineering \\ Technical University of Denmark \\ Brovej, Building 118 \\ 2800 Kgs. Lyngby \\ Denmark \\ Tel. (+45) 45251858 \\ E-mail: marmo@byg.dtu.dk \\ *Temporary contact information until April 2012: \\ NRC-IRC \\ 1200 Montreal Road, Bldg M-24 \\ Ottawa, Ontario, K1A 0R6 \\ Canada \\ Tel. (+1) (613) 993-8144
}

Svend Svendsen

Professor

Department of Civil Engineering

Technical University of Denmark

Brovej, Building 118

2800 Kgs. Lyngby

Denmark

Tel. (+45) 45251854

E-mail: ss@byg.dtu.dk

\section{ACKNOWLEDGEMENTS}

The financial support for this research is provided by the Landowners' Investment Association and by LavEByg, an innovation network for low-energy measures in buildings; this support is gratefully acknowledged. The authors would also like to thank Gregor A. Scheffler for initiating these investigations when he was a postdoctoral fellow at DTU Civil Engineering and as well Hans Janssen for the thorough discussions in which he engaged regarding moisture simulations and the highly useful information that we obtained through these efforts. 


\title{
SUBMITTED VERSION 1 - BEFORE PEER-REVIEW \\ MAJOR CHANGES WERE MADE TO THE FINAL VERSION OF THE PAPER \\ METHOD FOR INVESTIGATION OF INTERIOR POST-INSULATED \\ MASONRY WALLS WITH WOODEN BEAM ENDS
}

\begin{abstract}
The preponderant number of multi-story buildings constructed in Denmark (Northern Europe) in the period between 1850-1930 were built with masonry walls incorporating wooden floor beams. Given the nature of this construction, it is supposed that significant energy savings could be achieved by simply insulating the facades of such buildings. To maintain the exterior appearance of the facade the only possible means of installing the required insulation is placing it on the interior of the wall. However, the installation of insulation on the interior of the wall assembly reduces the overall drying potential of the wall, and this in turn may lead to moisture problems at the beam ends embedded in the masonry, when the masonry facade is subjected to driving rain. This paper presents a method to investigate retrofit measures of interior insulated masonry walls having wooden floor beams based on Failure Mode and Effect Analysis combined with hygrothermal simulations. The method was first used to determine the potential for failure in retrofitted walls, their effects and causes, and thereafter, the expected hygrothermal performance of the retrofit measures were further investigated using both thermal and hygrothermal simulation software. The results show that the risk to incurring moisture problems at wooden beam ends can be resolve by not insulating that portion of the wall directly above and below the floor division. Additionally, this proposed retrofit measure would reduce the heat loss of the original wall structure by half.
\end{abstract}

\section{KEYWORDS}

Failure Mode and Effect Analysis, Hygrothermal Performance, Energy Savings, Insulation, Wooden Beam, Wind-Driven Rain, Masonry 


\section{SUBMITTED VERSION 1 - BEFORE PEER-REVIEW \\ MAJOR CHANGES WERE MADE TO THE FINAL VERSION OF THE PAPER INTRODUCTION}

Within the Energy Performance of Buildings Directive it is stated, that buildings account for about $40 \%$ of the total energy consumption in Europe (EU, 2010). In other terms, this implies that energy consumption, as indicated in the directive, must be reduced by $20 \%$ by 2020 . However, to meet this objective, it has become apparent that simply building new energy efficient buildings would not permit meeting the energy reduction targets by 2020; the existing building stock would also need to be retrofit given that new buildings only represent a small portion of the total building stock in the EU. But which set of existing buildings would be considered the most likely for energy retrofits? It has been shown that multi-storey buildings erected in the period between 1850 and 1930 have a substantial energy savings potential if considering the retrofitting of the facades of such buildings (Tommerup \& Svendsen, 2006; Wittchen, 2009). These buildings were built with solid masonry walls in which wooden floor beams are incorporated in and supported by the wall; a typical wall, as shown in Figure 1, has been described by Engelmark (1983).

a)

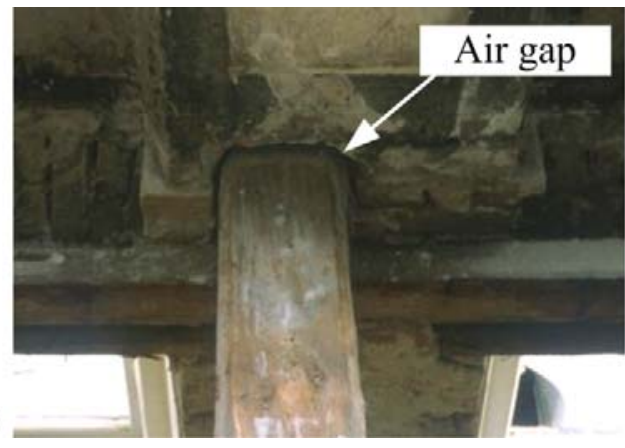

b)

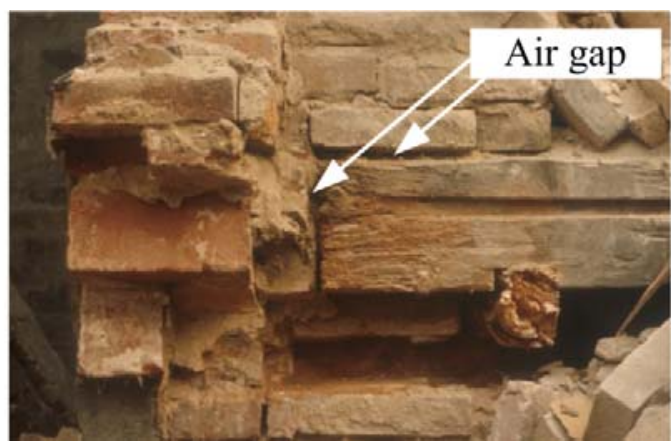

Figure 1. Beam ends supported in the pier. a) gap around the beam end seen from the front, b) the beam end seen from the side.

Given that the facade of such buildings are often worthy of preservation the only possible measure for retrofitting the walls is by installation of insulation on the interior of the wall. 


\section{SUBMITTED VERSION 1 - BEFORE PEER-REVIEW \\ MAJOR CHANGES WERE MADE TO THE FINAL VERSION OF THE PAPER}

The installation of insulation on the interior of the wall reduces the heat loss through the wall but it also reduces the drying potential of the wall by lowering temperatures. The lower wall temperatures increase the risk of condensation of water vapour that penetrates from the interior. This moisture penetration can be prevented by using a vapour barrier which then reduces the drying to the interior. However it has been shown that the amount of insulation installed on the interior, and that includes vapour barrier, might be affected in instances where the facade is subjected to high wind driven rain (WDR) loads (Morelli et al., 2010). In such instances where the WDR load is high, rain may accumulate in the masonry and thereafter cause a prolonged period of elevated moisture content of wooden beam ends that would cause the onset of the deterioration of the beams. Application of insulation on the interior of the wall does not only increase the risk of wood decay and mould growth of embedded wooden beams, it also takes up room space, and depending on the depth of the insulation installed, may take up to $0.2 \mathrm{~m} / \mathrm{m}^{2}$ floor area for insulation of $200 \mathrm{~mm}$ depth.

This paper presents a methodology for thoroughly assessing retrofit measures on brick masonry walls based on Failure Mode and Effect Analysis (FMEA) combined with hygrothermal simulation. The study focuses on the retrofit of solid masonry walls having embedded wooden beams and the development of appropriate retrofit measures in which the long-term hygrothermal performance of the wall is ensured. This is an important consideration as without some assurance that the retrofit can function adequately over the long-term, the potential energy savings from the addition of insulation cannot be realised. The use of FMEA permits identifying possible failures whereas the use of hygrothermal simulation allows understating the consequences of such failures on the performance of individual components as well as the wall as a whole. In instances where retrofit measures are not shown to provide advantage to the long-term performance of the wall assembly, alternative measures can be proposed and re-evaluated through simulation. 


\section{SUBMITTED VERSION 1 - BEFORE PEER-REVIEW}

\section{MAJOR CHANGES WERE MADE TO THE FINAL VERSION OF THE PAPER}

\section{Overview of Related Studies on Masonry Walls having Wooden Beams}

Krebs and Collet (1981) undertook temperature and moisture content measurements in 30 wooden beam ends where some walls were insulated on the interior of the wall with $150 \mathrm{~mm}$ insulation and others not insulated. They concluded that the driving rain did not have a significant influence on moisture uptake and consequently there would only be a very limited risk for moisture problems to occur at beam ends. Christensen and BunchNielsen (2009) collected information from several measurements and concluded that driving rain could be problematic if the facade had cracks. However, of no cracks were present in the masonry facade thorough which water could penetrate during rain events, then up to $150 \mathrm{~mm}$ of insulation could be applied to the interior of the wall and not cause any deterioration of wooden beam ends. Munch-Andersen (2008) described the application of mineral wool insulation together with a vapour barrier as sufficient set of components in the wall assembly to prevent vapour penetration from the interior. The vapour barrier was made tight to the floor; therefore diffusion through the floor could still be possible. In this particular study the driving rain was not seen as a problem as long as the facade was free of cracks and also included fully bedded joints. Rasmussen (2010) further investigated the critical moisture conditions for wooden beam ends based entirely on the effects of vapour diffusion. He concluded that exterior moisture did not pose a problem to the risk of heightened moisture content at beam ends given that the exterior moisture content was below that evident at beam ends. Rasmussen (2010) also listed limitations for the indoor environment to ensure that diffusion from inside would not contribute to any risk of damage to beam ends. Häupl (2010) investigated infiltration of room air into beam ends. The results showed that, on the one hand, at higher air velocities there was temperature increase hence a reduce risk to the formation of high moisture contents at beam ends, whereas on the other hand, condensation in cavities at beam ends did occur at intermediate air velocities. Häupl (2010) suggested therefore insulating the beam end cavity or applying a local outside insulation to increase the temperature of the surfaces around the beam end. Insulation on the interior of the wall was applied between floor and ceiling (Feist, 2005) but also applied insulation between 


\section{SUBMITTED VERSION 1 - BEFORE PEER-REVIEW \\ MAJOR CHANGES WERE MADE TO THE FINAL VERSION OF THE PAPER}

the beams in the floor division. For this safe measure measurements of wood moisture content are in the range of $10-20 \%$.

A capillary-active insulation material could be used instead of mineral wool and vapour barrier. Häupl et al. (2004) investigated the use of calcium silicate as an insulation component and found no problems with the wooden beam structure after two years of study. However, the test building in which the studies were completed did not have high wind-driven rain loads in part due to a large roof overhang that shielded the facade during less intense rain events. The investigations showed no problems with an interior climate having $70 \%$ relative humidity. Another comparable study by Häupl et al. (2006) provided similar results. In this more recent study, driving rain penetrated $300 \mathrm{~mm}$ into the outer brick masonry wall (i.e. halfway into wall assembly), and such occurrences could have been critical for ensuring the durability of wooden beam ends in this wall. In Häupl et al. (2003) and Stopp and Strangfeld (2006) a measure in which calcium silicate was used together with that of elevating the temperature of beam ends with heating pipes were investigated. Using heating pipes the measured moisture content in the beam end was below the calculated moisture content. Under operation the heating pipes had a negligible thermal bridging effect.

In all investigations the $U$-value of the wall was reduced by $33-50 \%$ and the temperature at the beam end dropped by only about $3^{\circ} \mathrm{C}$.

On the one hand the information obtained from the literature review indicates that insulation installed on the interior of the wall is not at problem as long as wind-driven rain is kept out of the wall. In the studies completed by Krebs and Collet (1981) and Christensen and Bunch-Nielsen (2009) the amount of wind-driven rain to which the facades were subjected was not provided; it is unclear then under which climate conditions and hence locations the retrofit measure might be durable. Munch-Andersen (2008) suggested a retrofit measure based entirely on thermal simulations and Rasmussen (2010) followed up with hand calculations based on temperature and relative humidity. In none of the above studies was a detailed hygrothermal simulation conducted in which 


\section{SUBMITTED VERSION 1 - BEFORE PEER-REVIEW}

\section{MAJOR CHANGES WERE MADE TO THE FINAL VERSION OF THE PAPER}

wind-driven rain intensity also considered as a parameter. On the other hand, several studies, such as those undertaken by Häupl et al. (2003), Feist (2005), Stopp and Strangfeld (2006) and Häupl (2010) have suggested measures to reduce the moisture content at the wooden beam, i.e., by increasing the temperature at this location. The retrofit measures suggested from these studies were all very extensive and would not likely be affordable. According to Krebs and Collet (1981), the problems with insulation installed on the interior of masonry brick walls, and in which wooden beams are embedded are that the moisture conditions at the beam end depend on many factors, the most significant of which are:

- Geometry of the structure

- Interior temperature and relative humidity

- Production of interior moisture

- Outside climate (i.e. temperature, relative humidity, driving rain intensity and wind velocity)

- Material properties for wood and masonry

- Air changes around the beam end

\section{Failure Mode and Effect Analysis}

Failure Mode and Effect Analysis (FMEA) is a quality planning tool that provides a systematic and analytical process for identifying hazards and risks for manufactured or built components. FMEA was developed in the aerospace industry and has been adapted in many other lines of business. In Figure 2, the three general steps of the FMEA process are shown as described by McDermott et al. (2009) and Stamatis (2003). The FMEA method is chosen based on the bottom-up approach where failures are exhaustively catalogued and the corresponding effects that ensue from these failures identified. In instances where retrofitting scenarios of buildings is considered, the FMEA was determined as a usable tool to help assess the effect of failure of different building components on the overall performance of the building. 


\section{SUBMITTED VERSION 1 - BEFORE PEER-REVIEW}

\section{MAJOR CHANGES WERE MADE TO THE FINAL VERSION OF THE PAPER}

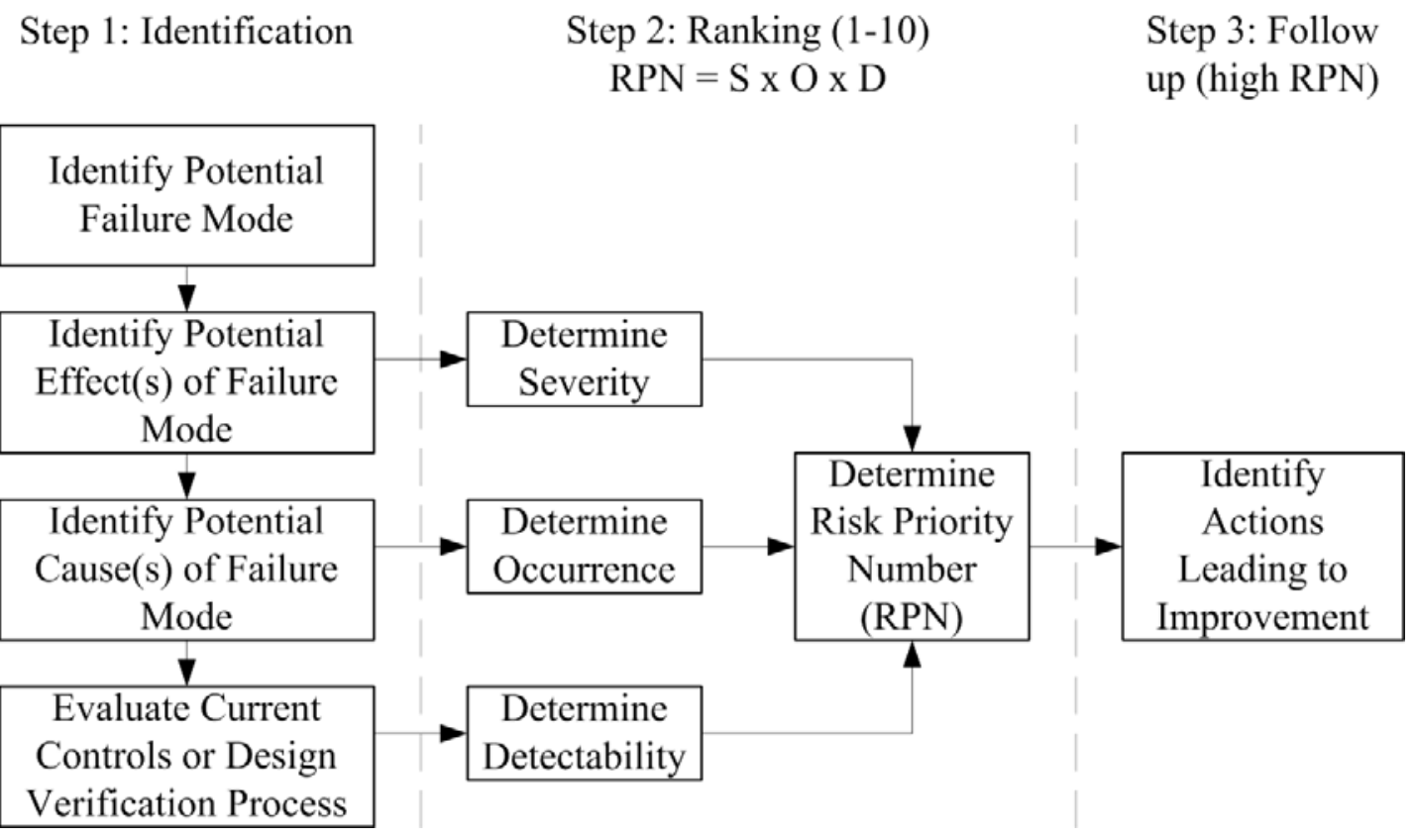

Figure 2. Failure Mode and Effect Analysis processes based on work by McDermott et al. (2009) and Stamatis (2003).

A state of the art work on the use of FMEA in building construction was prepared by Talon et al. (2006) in which several examples on the use of FMEA are presented and in Talon (2006) the FMEA for an insulated brick cavity wall is presented. The FMEA used in this study, and described in this paper, only focused on Step 1 (Figure 2) which is the identification of failure modes and related effects. According to Mao et al. (2011) moisture is the most crucial factor causing deterioration of the building envelope. Hence the focus of the hygrothermal simulations is therefore found on the basis of the failures identified from the FMEA process.

\section{STRUCTURE OF ASSEMBLY}

The existing masonry wall had a thickness of $460 \mathrm{~mm}$. The wall consisted of brick masonry units ( $80 \times 220 \mathrm{~mm})$ separated by $20 \mathrm{~mm}$ lime-cement mortar. The inside of the existing wall was $30 \mathrm{~mm}$ lime plaster layer. The outer $220 \mathrm{~mm}$ of the beam end was supported in the wall on one side and there was an air gap of $20 \mathrm{~mm}$ on all other 


\section{SUBMITTED VERSION 1 - BEFORE PEER-REVIEW}

\section{MAJOR CHANGES WERE MADE TO THE FINAL VERSION OF THE PAPER}

sides between the beam and the masonry wall. The beam was $140 \mathrm{~mm}$ high with wooden floor boards of $30 \mathrm{~mm}$ on top.

The retrofitted structure was investigated with $100 \mathrm{~mm}$ and $200 \mathrm{~mm}$ inside insulation. The inside insulation was investigated with a gap of $200 \mathrm{~mm}$ and without a gap towards the floor, see Figure 3. Between the insulation and gypsum board a vapour barrier was placed. In the cases with an insulation gap the vapour barrier was placed horizontally under the insulation. The framework in the insulation should preferably be built up by steel than wood due to deterioration.
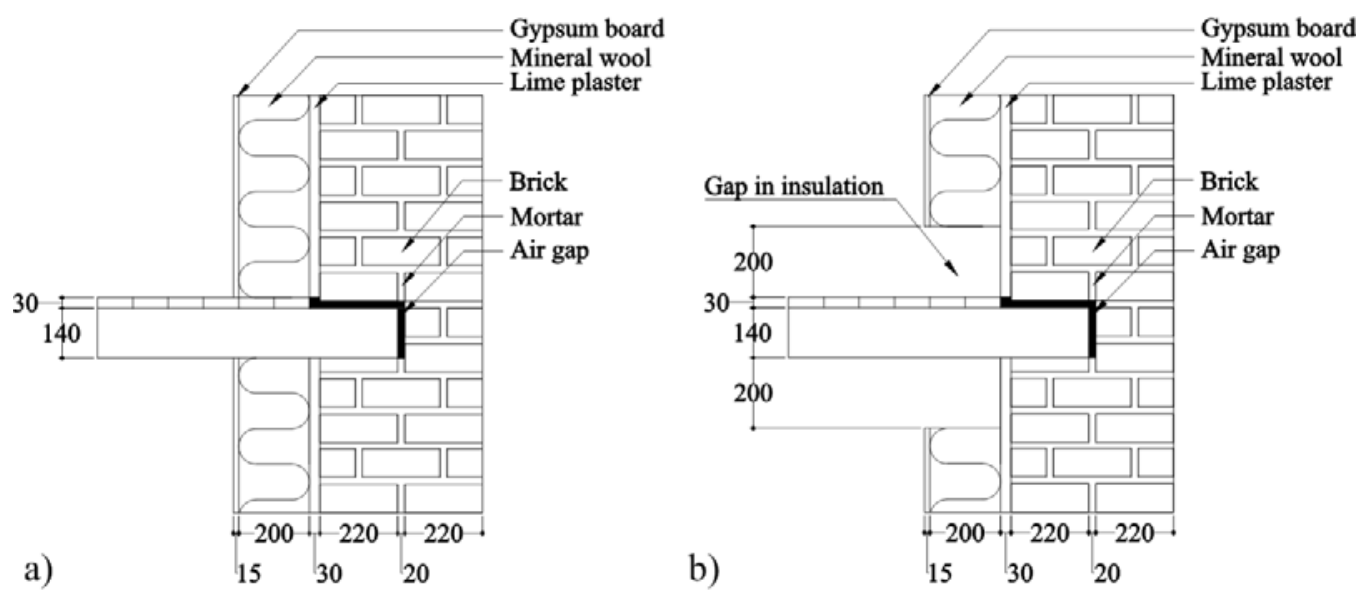

Figure 3. Detailed description of beam end and wall joint. Between the gypsum board and mineral wool the vapour barrier was placed. a) Show the measure without a gap and b) show the applied insulation with a gap.

\section{Materials and Boundary Conditions}

The basic material properties used for the heat and moisture simulations are listed in Table 1 and taken from DELPHIN (Grunewald, 1997; Nicolai et al., 2010). The vapour barrier had a vapour diffusion thickness of $2 \mathrm{~m}$. 


\section{SUBMITTED VERSION 1 - BEFORE PEER-REVIEW}

\section{MAJOR CHANGES WERE MADE TO THE FINAL VERSION OF THE PAPER}

Table 1. Material properties for hygrothermal simulations.

\begin{tabular}{lcccc}
\hline & Thermal & Density & Water vapour diffusion & Water absorption \\
& conductivity & & resistance factor & coefficient \\
& $\lambda_{\text {dry }}$ & $\rho$ & $\mu$ & $A_{w}$ \\
& $W /(\mathrm{m} \cdot \mathrm{K})$ & $\mathrm{kg} / \mathrm{m}^{3}$ & {$[-]$} & $\mathrm{Kg} /\left(\mathrm{m}^{2} \cdot \mathrm{s}^{0.5}\right)$ \\
& 0.91 & 1800 & 13 & 0.227 \\
\hline Brick & 0.70 & 1600 & 30 & 0.300 \\
Lime-cement mortar & 0.82 & 1800 & 12 & 0.127 \\
Lime Plaster & 0.13 & 530 & 40 & 0.058 \\
Spruce (wood) & 0.14 & 1.29 & 0.5 & - \\
Air layer (25 mm) & 0.04 & 30 & 1 & - \\
Mineral wool & 0.20 & 850 & 10 & 0.277 \\
Gypsum board & & & & \\
\hline
\end{tabular}

The interior climate was described by boundary conditions with a constant air temperature of $20^{\circ} \mathrm{C}$ and $50 \%$ relative humidity. When carrying out simulations in respect to determining the thermal performance for the wall assembly in respect to energy losses, the exterior climate was described by a constant temperature of $0^{\circ} \mathrm{C}$. This temperature was chosen to give an early indication of the energy saving potential of the different retrofit measures. In respect to completing the hygrothermal simulations the hourly test reference year for Bremerhaven (Germany) was used as exterior climate and this information was obtained from Nicolai et al. (2010). Figure 4 shows the hourly values for the temperature and relative humidity of Bremerhaven over a year based on average data from 1961-1990.This reference year was the best representative for Denmark in which rain data is also available, as there is currently no corresponding reference year data available for locations in Denmark. In Figure 5 the average wind speed and wind driven rain index $\left(\mathrm{I}_{\mathrm{WDR}}\right)$ are provided for the same location and the same year. The wind driven rain index was obtained from Eq. (1) where $i$ is the azimuth angle ( $0=$ North). It is 


\section{SUBMITTED VERSION 1 - BEFORE PEER-REVIEW}

\section{MAJOR CHANGES WERE MADE TO THE FINAL VERSION OF THE PAPER}

apparent from the information provided in Figure 5 that the prevalent direction for both the wind and winddriven rain is southwest.

$$
I_{W D R}=\frac{\sum_{i-15}^{i+15} v_{\text {wind }_{i}} \cdot R_{H_{i}}}{\sum_{0}^{360} R_{W D R}} ; i=[0,30, \ldots, 360]
$$

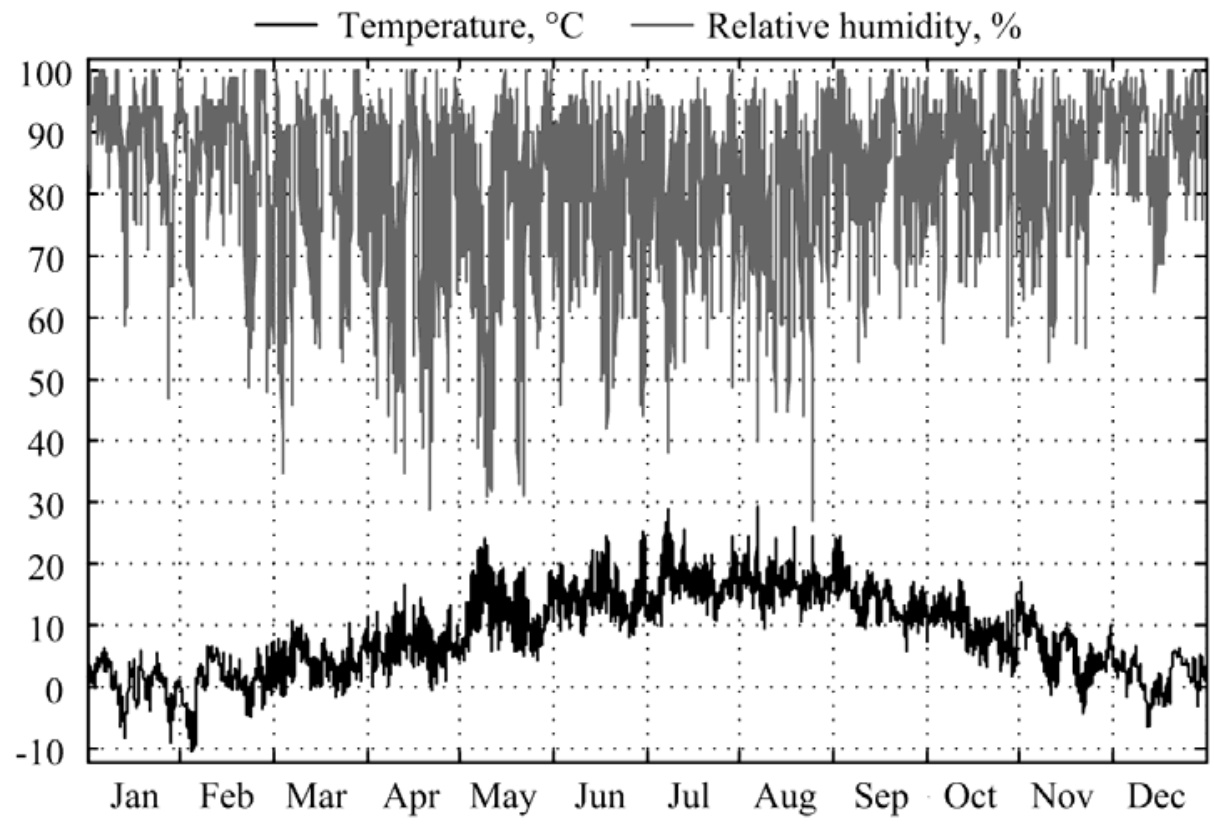

Figure 4. Temperature and relative humidity for Bremerhaven.

a)

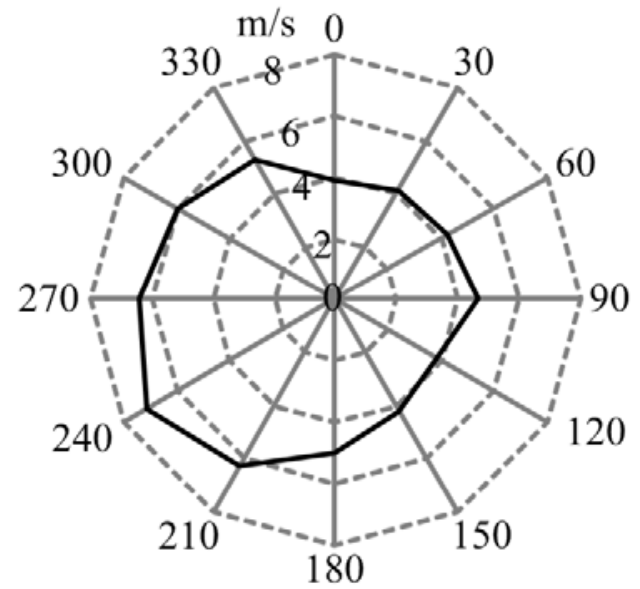

b)

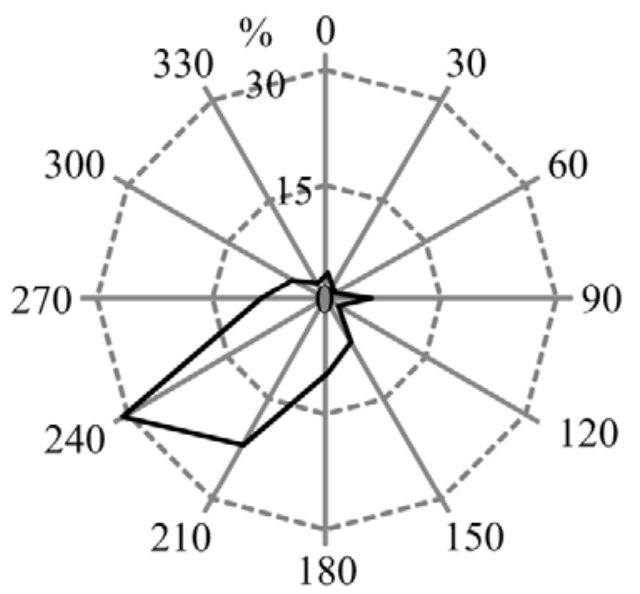




\section{SUBMITTED VERSION 1 - BEFORE PEER-REVIEW \\ MAJOR CHANGES WERE MADE TO THE FINAL VERSION OF THE PAPER}

Figure 5. Weather data for Bremerhaven. a) Average air velocity and b) Wind-driven rain.

The thermal surface resistances of the different building components were defined according to (EN ISO 6946, 2007) and the values are given in Table 2 . The outside surface resistance was consistent with values obtained using the approach described by Blocken et al. (2009) and Sharples (1984) for forced convective heat transfer coefficients on a windward surface in which the radiant heat transfer coefficient is also considered.

Table 2. Thermal surface resistances for thermal simulations.

\begin{tabular}{lccc} 
Surface & $\begin{array}{c}\text { Heat flow (upwards) } \\
\left(\mathrm{m}^{2} \cdot \mathrm{K}\right) / \mathrm{W}\end{array}$ & $\begin{array}{c}\text { Heat flow (horizontal) } \\
\left(\mathrm{m}^{2} \cdot \mathrm{K}\right) / W\end{array}$ & $\begin{array}{c}\text { Heat flow (downwards) } \\
\left(\mathrm{m}^{2} \cdot \mathrm{K}\right) / W\end{array}$ \\
\hline Inside & 0.10 & 0.13 & 0.17 \\
Outside & 0.04 & 0.04 & 0.04 \\
\hline
\end{tabular}

The values for the vapour diffusion coefficients influence the evaporative drying of the facade. High values for the vapour diffusion coefficients increase evaporation during rain events but decrease the amount of surface runoff. The values for the vapour diffusion coefficients were calculated according to (Janssen et al., 2007) using the Lewis analogy of $16.8 \cdot 10^{-8} \mathrm{~s} / \mathrm{m}$ (windward) and $7.6 \cdot 10^{-8} \mathrm{~s} / \mathrm{m}$ (leeward). The values for the vapour diffusion coefficients, for the interior and exterior surfaces respectively, were $3 \cdot 10^{-8} \mathrm{~s} / \mathrm{m}$ and $8 \cdot 10^{-8} \mathrm{~s} / \mathrm{m}$. The latter choices were considered conservative values.

The hydraulic contact at the brick-mortar interface was considered to be imperfect (Derluyn et al., 2011), which meant that a hydraulic resistance was present at this interface. The interface resistance were found in the range $1.25 \cdot 10^{10}-2.5 \cdot 10^{10} \mathrm{~m} / \mathrm{s}$. The degree of water transport between the brick and lime-cement mortar was calculated assuming a surface water resistance of $5 \cdot 10^{10} \mathrm{~m} / \mathrm{s}$. 


\section{SUBMITTED VERSION 1 - BEFORE PEER-REVIEW \\ MAJOR CHANGES WERE MADE TO THE FINAL VERSION OF THE PAPER CALCULATION METHOD}

\section{Thermal Calculations}

The energy saving potential was investigated using the $2 \mathrm{D}$ thermal calculation as is configured in HEAT2 (Blomberg, 1996, 2010). The thermal performance of the structures was assessed based on the coupling coefficient, $\mathrm{L}_{2 \mathrm{D}}$, that is directly available from HEAT2. Using the coupling coefficient, the different retrofit measures for which the installation of insulation with and without a gap above the floor plate were considered, were directly compared in respect to the heat loss.

\section{Hygrothermal Calculations}

The coupled heat and moisture investigations were completed using DELPHIN (Grunewald, 1997; Nicolai et al., 2010). The wall assemblies that were analysed faced west in respect to the rain and wind load in the weather data. The masonry was assumed to be perfect; hence, cracks and infiltration were neglected. The rain exposure coefficient, $\mathrm{k}_{\text {rain, }}$, was varied between 0.1 and 0.5 and was a way to reduce the wind-driven rain on the facade. The results of this simulation study were focused on obtaining the relative humidity and moisture content at the top corner of the beam end that was embedded in the masonry structure. As well, the likelihood of the presence of mould growth, the inside masonry in which a gap was present in the insulation at the interior was investigated.

\section{Wind-Driven Rain}

The rain flux density normal to the wall surface was calculated from information on wall inclination and orientation, the rain flux density on a horizontal plane, the wind direction and wind velocity as provided in Eq.

(2) to Eq. (4)

$$
j_{\text {rain, nor }}=k_{\text {wind }} \cdot k_{\text {rain }} \cdot j_{\text {rain,hor }}
$$




\section{SUBMITTED VERSION 1 - BEFORE PEER-REVIEW}

\section{MAJOR CHANGES WERE MADE TO THE FINAL VERSION OF THE PAPER}

where $\mathrm{k}_{\text {wind }}$ is the wind coefficient (catch ratio) [-] determined from Eq. (3), $\mathrm{k}_{\text {rain }}$ is the rain exposure coefficient $[-]$ and $\mathrm{j}_{\text {rain,hor }}$ is the rain flux density on a horizontal plane $\left[\mathrm{kg} /\left(\mathrm{m}^{2} \cdot \mathrm{s}\right)\right]$.

$$
k_{\text {wind }}=\left\{\begin{array}{c}
0 \text { if }\left(\beta_{\text {wind }} \geq \frac{\pi}{2}\right) \vee\left(v_{\text {wind }} \leq 0\right) \\
\frac{\cos \left(\beta_{\text {wind }}\right)}{\sqrt{1+1141 \cdot \sqrt{\frac{3600 \cdot j_{\text {rain,hor }}}{v_{\text {wind }}^{4}}}}} \cdot \exp \left(-\frac{12}{5 \cdot \sqrt[4]{3600 \cdot j_{\text {rain,hor }}}}\right)
\end{array}\right.
$$

where $\beta_{\text {wind }}$ is the wind angle $\left[^{\circ}\right]$ determined from Eq. (4) and $\mathrm{v}_{\text {wind }}$ is the wind velocity $[\mathrm{m} / \mathrm{s}]$.

$$
\beta_{\text {wind }}=\left\{\begin{array}{c}
\left|\alpha_{\text {wall }}-\alpha_{\text {wind }}\right| \text { if }\left|\alpha_{\text {wall }}-\alpha_{\text {wind }}\right| \leq \pi \\
2 \pi-\left|\alpha_{\text {wall }}-\alpha_{\text {wind }}\right|
\end{array}\right.
$$

where $\alpha_{\text {wall }}$ and $\alpha_{\text {wind }}$ is the wall orientation and wind direction.

\section{RESULTS}

The masonry brick wall assembly was investigated in various configurations that included: (i) the reference condition in which the assembly prior to retrofit measures is considered and for which no insulation was used, i.e. $0 \mathrm{~mm}$; (ii) retrofitted wall assembly where $100 \mathrm{~mm}$ and $200 \mathrm{~mm}$ of mineral wool insulation with a vapour barrier were installed to the interior of the assembly.

The FMEA was carried out in regards to the different functions of individual components of the wall assembly; these functions are given in Table 3. The primary functions are the ones concerning the hygrothermal performance (i.e. items 1-7) and each of these is considered in the FMEA. Table 4 shows the FMEA for each of the different components in the wall assembly and for which the related potential failures, and their effects and causes are also provided. 


\section{SUBMITTED VERSION 1 - BEFORE PEER-REVIEW}

\section{MAJOR CHANGES WERE MADE TO THE FINAL VERSION OF THE PAPER}

Table 3. Functions of outer wall and beam end.

\begin{tabular}{lll}
\hline Primary & Secondary \\
\hline 1 & Structural performance & 8 Sound \\
2 & Water resistance & 9 Fire safety \\
3 & Air tightness (infiltration) & 10 Security \\
4 & Condensation (surface/interior) & 11 Maintainability \\
5 & Accommodate movement & 12 Constructability \\
6 & Energy conservation & 13 Aesthetics \\
7 & Durability & 14 Economy
\end{tabular}

Table 4. Failure Mode and Effect Analysis for inside insulated masonry wall with wooden floor beam.

\begin{tabular}{|c|c|c|c|}
\hline Component & Potential Failure Mode & Potential Effect(s) of Failure & Potential Cause(s) of Failure \\
\hline \multirow[t]{3}{*}{ Brick } & Cracking & $\begin{array}{l}\text { Water permeability } \\
\text { Collapse }\end{array}$ & $\begin{array}{l}\text { - Manufacturing fault } \\
\text { - Shock } \\
\text { - Movements (moisture, } \\
\text { temperature, structural) } \\
\text { - Freeze-thaw cycles } \\
\text { - Foundation subsidence } \\
\text { - Cleaning (graffiti) }\end{array}$ \\
\hline & Porosity & $\begin{array}{l}\text { Water permeability } \\
\text { Freezing sensitivity }\end{array}$ & $\begin{array}{l}\text { - Material selection } \\
\text { - Freeze-thaw cycles } \\
\text { - Cleaning (graffiti) }\end{array}$ \\
\hline & Loose bricks & $\begin{array}{c}\text { Water permeability } \\
\text { Loss of load carrying capacity } \\
\text { Collapse }\end{array}$ & $\begin{array}{l}\text { - Movements of wall } \\
\text { - Movement of beam end } \\
\text { - Shock }\end{array}$ \\
\hline
\end{tabular}


SUBMITTED VERSION 1 - BEFORE PEER-REVIEW

MAJOR CHANGES WERE MADE TO THE FINAL VERSION OF THE PAPER

\begin{tabular}{|c|c|c|c|}
\hline & & & - Mortar adherence \\
\hline & Salt precipitation & Water absorption & $\begin{array}{l}\text { - Salting in winter } \\
\text { - Salts in bricks }\end{array}$ \\
\hline & $\begin{array}{l}\text { Low temperatures } \\
\text { (insulation) }\end{array}$ & $\begin{array}{l}\text { Moisture accumulation } \\
\text { Loss of drying potential }\end{array}$ & - Inside insulation \\
\hline & Spalling & $\begin{array}{l}\text { Water permeability } \\
\text { Freezing sensitivity }\end{array}$ & $\begin{array}{l}\text { - Freeze-thaw cycles } \\
\text { - Cleaning (graffiti) }\end{array}$ \\
\hline \multirow[t]{4}{*}{ Mortar } & Cracking & Water permeability & $\begin{array}{l}\text { - Shock } \\
\text { - Movements(moisture, } \\
\text { temperature, structural) } \\
\text { - Freeze-thaw cycles } \\
\text { - Foundation subsidence } \\
\text { - Cleaning (graffiti) }\end{array}$ \\
\hline & $\begin{array}{c}\text { Loss of adherence to } \\
\text { bricks }\end{array}$ & Water permeability & $\begin{array}{l}\text { - Amount of mortar } \\
\text { - Drying of mortar } \\
\text { - Movements in wall }\end{array}$ \\
\hline & Weathered & $\begin{array}{c}\text { Water permeability } \\
\text { Infiltration }\end{array}$ & - Wind and rain (weather) \\
\hline & $\begin{array}{l}\text { Joints not filled with } \\
\text { mortar }\end{array}$ & Water permeability & - Workmanship \\
\hline \multirow[t]{3}{*}{ Beam end } & Moisture absorption & $\begin{array}{c}\text { Wood decay } \\
\text { Swelling }\end{array}$ & $\begin{array}{l}\text { - Built in moisture } \\
\text { - Change in moisture balance } \\
\text { - Reduced drying potential }\end{array}$ \\
\hline & $\begin{array}{c}\text { Reduce drying from beam } \\
\text { end }\end{array}$ & $\begin{array}{l}\text { Moisture accumulation } \\
\text { Swelling }\end{array}$ & $\begin{array}{l}\text { - Roofing membrane (other } \\
\text { treatment of beam end) }\end{array}$ \\
\hline & Condensation & Mould & - Temperature variation \\
\hline
\end{tabular}


SUBMITTED VERSION 1 - BEFORE PEER-REVIEW

MAJOR CHANGES WERE MADE TO THE FINAL VERSION OF THE PAPER

\begin{tabular}{|c|c|c|c|}
\hline \multirow{5}{*}{$x^{2}$} & 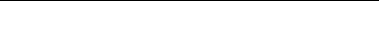 & & - Infiltration of warm humid air \\
\hline & Loss of base & Collapse & $\begin{array}{l}\text { - Movement of wall } \\
\text { - Deterioration of wood }\end{array}$ \\
\hline & Wood decay & Collapse & $\begin{array}{l}\text { - Moisture accumulation } \\
\text { - Wood rot }\end{array}$ \\
\hline & $\begin{array}{l}\text { Air movement into the } \\
\text { beam }\end{array}$ & Condensation & $\begin{array}{l}\text { - Vapour open floor } \\
\text { - Draughty vapour barrier }\end{array}$ \\
\hline & Shrinking & $\begin{array}{c}\text { Cracks in bricks } \\
\text { Subsidence }\end{array}$ & $\begin{array}{l}\text { - Lack of fit } \\
\text { - Increased drying }\end{array}$ \\
\hline \multirow[t]{2}{*}{ Lime Plaster } & Mould growth & Hygiene (mould) & - Local cold surface \\
\hline & Cracks (fall off) & Moisture diffusion & $\begin{array}{l}\text { - Shock } \\
\text { - Movements (moisture, } \\
\text { temperature, structural) }\end{array}$ \\
\hline \multirow[t]{6}{*}{$\begin{array}{l}\text { Insulation (Mineral } \\
\text { wool) }\end{array}$} & Rot of wood framework & Structural & $\begin{array}{l}\text { - Condensation } \\
\text { - Moisture from in-/outside }\end{array}$ \\
\hline & Moisten & Loss of thermal performance & $\begin{array}{l}\text { - Condensation } \\
\text { - Moisture from in-/outside }\end{array}$ \\
\hline & Increased cold bridges & Mould in corners / surfaces & - Reduced temperatures \\
\hline & Mould (brick-insulation) & Hygiene & $\begin{array}{l}\text { - Draughty vapour barrier } \\
\text { - Moisture from outside }\end{array}$ \\
\hline & Summer condensation & $\begin{array}{c}\text { Mould and rot on floor where } \\
\text { vapour barrier is tighten }\end{array}$ & $\begin{array}{l}\text { - Choice of vapour barrier } \\
\text { - Reduced drying to the inside }\end{array}$ \\
\hline & $\begin{array}{c}\text { Loss of thermal insulation } \\
\text { performance }\end{array}$ & Increase heat loss & - Integrated cold bridge \\
\hline Vapour barrier & Piercing, tear, bad joints & $\begin{array}{l}\text { Vapour diffusion into the wall } \\
\text { Interstitial condensation }\end{array}$ & $\begin{array}{l}\text { - Workmanship } \\
\text { - Occupant behaviour }\end{array}$ \\
\hline
\end{tabular}


SUBMITTED VERSION 1 - BEFORE PEER-REVIEW

MAJOR CHANGES WERE MADE TO THE FINAL VERSION OF THE PAPER

\begin{tabular}{|c|c|c|c|}
\hline & & & - Design \\
\hline & $\begin{array}{l}\text { Missing } \\
\text { Wrong position in wall } \\
\text { Type of vapour barrier }\end{array}$ & $\begin{array}{c}\text { Mould } \\
\text { Rot of framework }\end{array}$ & $\begin{array}{l}\text { - Workmanship } \\
\text { - Design }\end{array}$ \\
\hline Gypsum board & Surface mould & Hygiene & $\begin{array}{l}\text { - Increased RH in indoor air } \\
\text { - Tighter building }\end{array}$ \\
\hline
\end{tabular}

From Table 4 it is seen that most failures relate to the masonry including mortar, the beam ends and the interior insulation. The most consequential effect appears to be the collapse of the assembly as a result of the deterioration of the beam end. This is a long term process and it is located in an area without direct access. This effect comes about due to the influence of water intrusion to the wall assembly. The most common effect is the moisture sources from inside, outside and when condensation inside the structure occurs. A side effect of this is the growth of mould and wood decay. It is therefore, necessary to investigate how the beam end will perform in the presence of moisture at the beam end but also determine how the brick-insulation interface may affect the growth of mould at these locations.

\section{Energy Savings}

The U-value for the existing wall is $1.40 \mathrm{~W} /\left(\mathrm{m}^{2} \cdot \mathrm{K}\right)$ (no insulation), and for the two insulated walls is 0.30 $\mathrm{W} /\left(\mathrm{m}^{2} \cdot \mathrm{K}\right)(100 \mathrm{~mm}$ insulation $)$ and $0.17 \mathrm{~W} /\left(\mathrm{m}^{2} \cdot \mathrm{K}\right)(200 \mathrm{~mm}$ insulation) respectively. In Table 5 , the coupling coefficients and linear heat loss transmittances are given for the existing structure, as well as those two wall assemblies for which interior retrofit measures to install insulation were made. The heat loss through the floor and wall is lowest if the insulation is applied to the floor and ceiling and no gap is present in the insulation, as shown in Figure 3a. 


\section{SUBMITTED VERSION 1 - BEFORE PEER-REVIEW}

\section{MAJOR CHANGES WERE MADE TO THE FINAL VERSION OF THE PAPER}

Table 5. Heat loss through wall and beam end.

\begin{tabular}{lcc}
\hline Insulation, & Gap size, & $L_{2 D}$, \\
$\mathrm{mm}$ & $\mathrm{Mm}$ & $W /(\mathrm{m})$ \\
\hline 0 & 0 & 58.3 \\
100 & 0 & 13.8 \\
100 & 200 & 28.4 \\
200 & 0 & 8.1 \\
200 & 200 & 25.5 \\
\hline
\end{tabular}

\section{Hygrothermal Calculations}

The points where the temperature, relative humidity and moisture content are measured are shown in

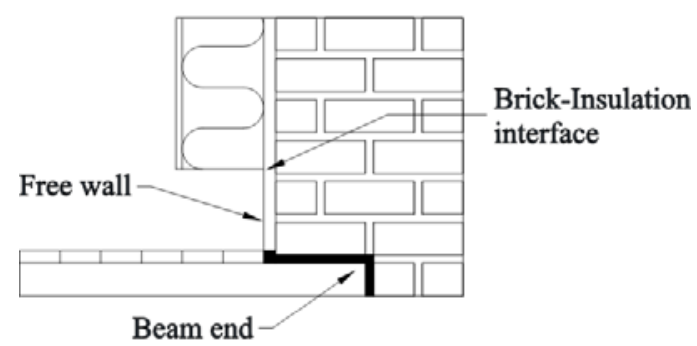

Figure 6.

Figure 6. Points for measurement of temperature, relative humidity and moisture content.

In regards to the potential for the formation of mould, wooden structures would normally be assessed in respect to the relative humidity $(\mathrm{RH})$ in the component with a critical level of $80-90 \% \mathrm{RH}$ for mould growth depending on the duration and temperature $\left(>5^{\circ} \mathrm{C}\right)$ (Sedlbauer, 2002). The critical moisture content (MC) for the initiation of growth of fungi in wood components would be $0.2 \mathrm{~kg} / \mathrm{kg}$ (Viitanen et al., 2010). The results of the simulation indicated that the reference case was shown to be durable given that the RH and MC of the components did not at any time exceed the critical values. Accordingly, it was assumed that the retrofit measures would likewise be 


\section{SUBMITTED VERSION 1 - BEFORE PEER-REVIEW}

\section{MAJOR CHANGES WERE MADE TO THE FINAL VERSION OF THE PAPER}

durable if the RH and MC do not exceed the critical limits as was found for the reference wall assembly. The results for temperature, $\mathrm{RH}$ and $\mathrm{MC}$ are average values for periods of 10 hours; for this reason some peaks values are not apparent.

\section{Influence of wind-driven rain on reference structure}

The wind-driven rain has a large influence on the $\mathrm{RH}$ and $\mathrm{MC}$ at the beam end. Figure 7 shows the variation in $\mathrm{RH}$ and $\mathrm{MC}$ at the beam end over a four year period for an un-insulated wall (reference) and for different rain exposure coefficients $(0.1,0.3$ and 0.5$)$. At lower rain exposure coefficients (i.e. $k_{\text {rain }}=0.1$ and 0.3$)$, the trend in relative humidity (Figure 7a) in the beam end over the months tends towards dropping below the critical RH of $80 \%$ after four years of exposure. The temperature is above $5^{\circ} \mathrm{C}$ in all 4 years, which could be an onset of mould growth $\left(\mathrm{k}_{\text {rain }}=0.3\right)$, but as the model needs to reach two consecutive uniform years, the structure is assessed to be durable. Also the structure has already existed for about 100 years. In the case of a wall subjected to a high rain exposure coefficient $\left(\mathrm{k}_{\text {rain }}=0.5\right)$ an upwards trend in $\mathrm{RH}$ is evident from the initial conditions of $80 \% \mathrm{RH}$ towards $100 \%$ RH.

a)

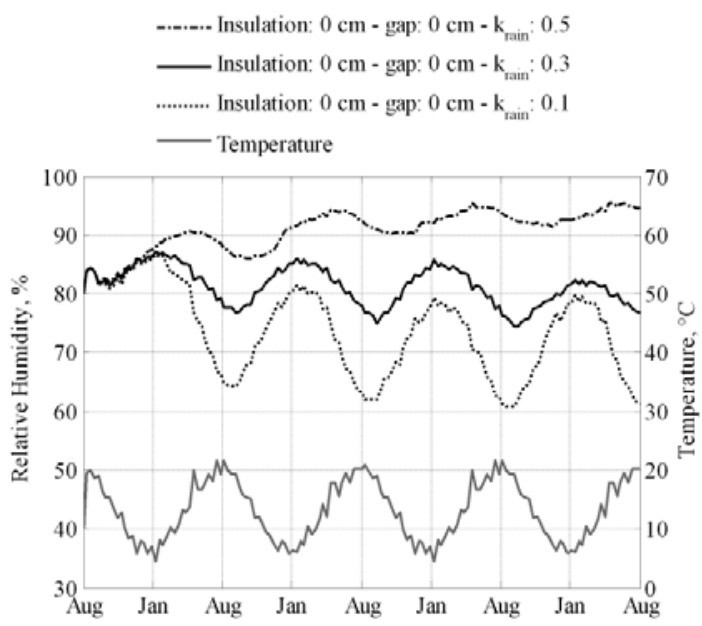

b)

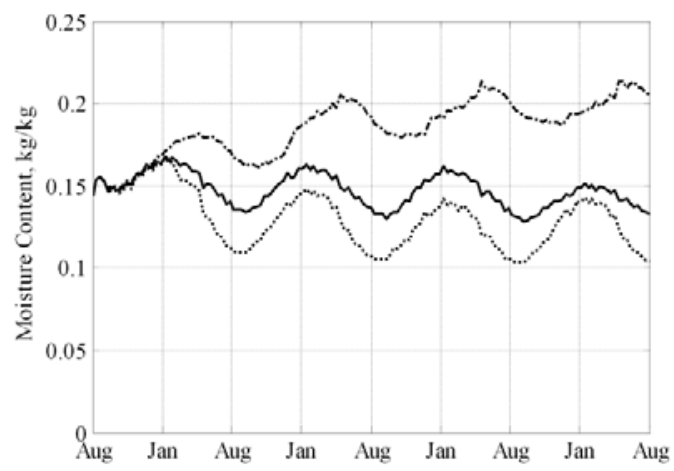

Figure 7. a) Relative humidity and temperature and b) moisture content in the beam end without inside insulation where $\mathrm{k}_{\text {rain }}$ is equal to $0.1,0.3$ and 0.5 . 


\section{SUBMITTED VERSION 1 - BEFORE PEER-REVIEW}

\section{MAJOR CHANGES WERE MADE TO THE FINAL VERSION OF THE PAPER}

It is apparent from Figure $7 \mathrm{~b}$ that the $\mathrm{MC}$ in the beam end at a rain exposure coefficient of 0.1 and 0.3 slightly decreases over four years. This in essence is the same trend as that for the relative humidity. Hence, with a rain exposure coefficient above 0.3 there is a risk that the MC curve will exceed the normal critical MC of $0.2 \mathrm{~kg} / \mathrm{kg}$ over a four year period.

\section{Retrofitted wooden beam end}

In the winter the temperature at the beam end drops $5-6^{\circ} \mathrm{C}$ down to the freezing point if insulation is installed at the interior of the wall in thicknesses of either $100 \mathrm{~mm}$ or $200 \mathrm{~mm}$ (Figure 8). If however a gap in the insulation is permitted the temperature will drop about $1{ }^{\circ} \mathrm{C}$ and still be about the $5^{\circ} \mathrm{C}$, whereas in the summer period there is no large difference in the temperature at the beam end regardless of the retrofit measures.

a)

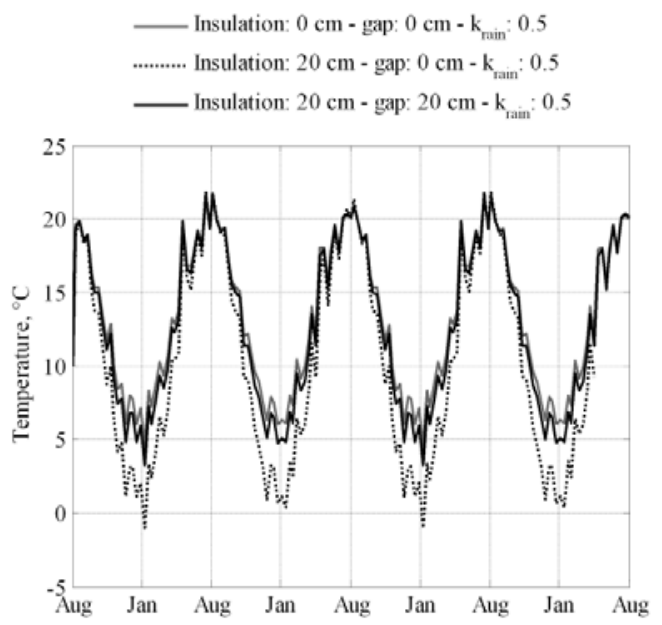

Figure 8. a) Temperature in the beam end for the reference, full insulated and partly insulated wall. b) The temperature deviation between the reference and retrofit measures.

Changes in $\mathrm{RH}$ and $\mathrm{MC}$ at the beam end for the different retrofit measures with a rain exposure coefficient of 0.1 are shown in Figure 9. It is apparent that development over the four year simulation period is the same whether 


\section{SUBMITTED VERSION 1 - BEFORE PEER-REVIEW}

\section{MAJOR CHANGES WERE MADE TO THE FINAL VERSION OF THE PAPER}

the retrofit measure is for the installation of $100 \mathrm{~mm}$ or $200 \mathrm{~mm}$ insulation thickness. The absolute maximum deviation between the results for $100 \mathrm{~mm}$ and $200 \mathrm{~mm}$ is about $\pm 7 \% \mathrm{RH}$ and $\mathrm{MC}$ of $\pm 0.02 \mathrm{~kg} / \mathrm{kg}$. At the low rain exposure coefficient, moisture dries out over a yearly cycle which gives larger intervals in the $\mathrm{RH}$ depending on the season. Installing insulation on the interior of the wall with a gap only raises the RH a few percentage points. For high rain exposure coefficients (e.g. 0.5) the retrofit measures will exceed the threshold values for mould growth and wood decay as shown for the reference case in Figure 7 as the trend for the retrofit measures are identical with the trend for $\mathrm{k}_{\mathrm{rain}}=0.1$.

a)

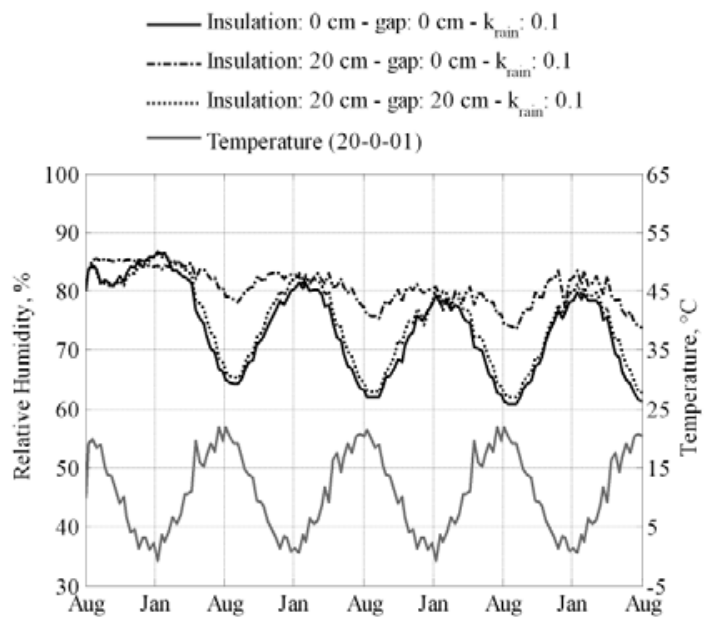

b)

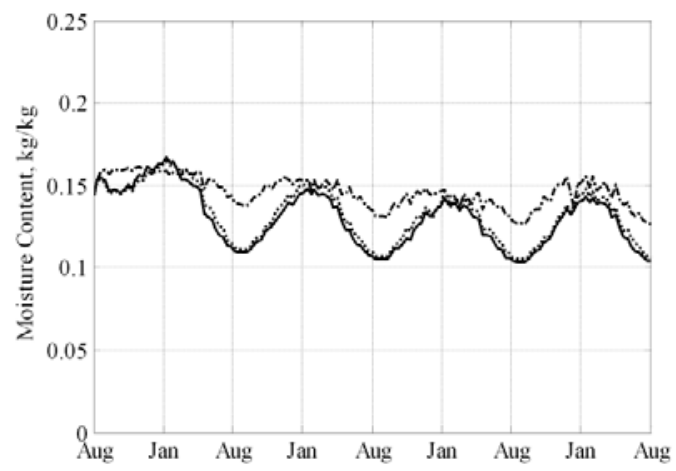

Figure 9. a) Relative humidity with temperature (for an entire insulated wall) and b) moisture content in the top corner of the beam end when applying $200 \mathrm{~mm}$ insulation with and without a gap where $\mathrm{k}_{\text {rain }}$ is 0.1 .

At an intermediate rain load $\left(\mathrm{k}_{\text {rain }}=0.3\right)$ an assessment can be based on the development found for the lower rain loads (Figure 9). The RH has a limited increase for retrofit measures that include a gap as compared to that of the reference wall, but the temperature will still remain above $5^{\circ} \mathrm{C}$. If insulation is installed on the entire interior wall there is a slight increase in $\mathrm{RH}$, but on the other hand the temperature drops below $5^{\circ} \mathrm{C}$ during the critical periods. Figure 10 shows the development in RH and MC if insulation is installed on the entire interior wall. As is perhaps evident in this Figure, this retrofit measure will not work if subjected to intermediate rain loads; 


\section{SUBMITTED VERSION 1 - BEFORE PEER-REVIEW}

\section{MAJOR CHANGES WERE MADE TO THE FINAL VERSION OF THE PAPER}

however, leaving a gap in the insulation could be a durable measure when considering the development of the lower rain loads.

a)

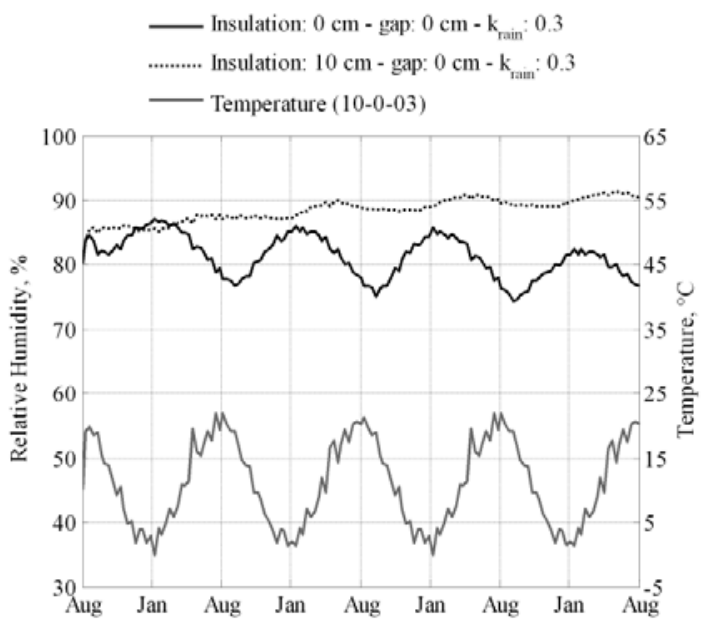

b)

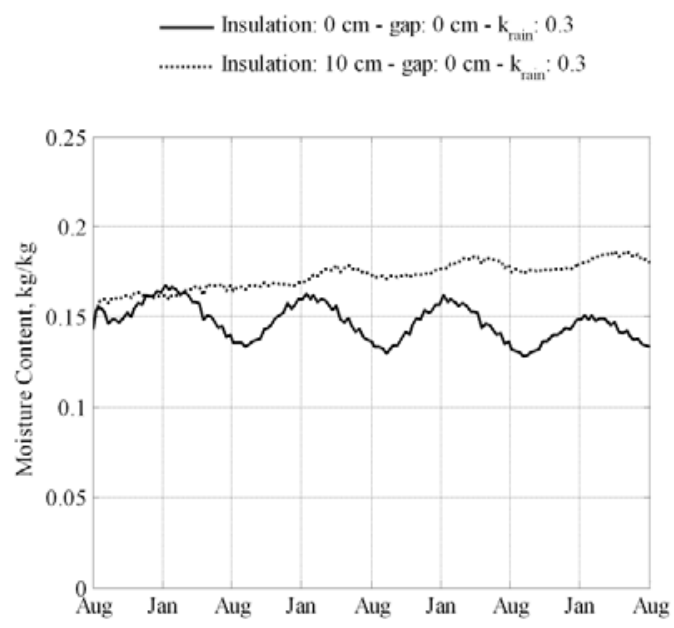

Figure 10. a) Relative humidity and temperature and b) moisture content in the beam end with $100 \mathrm{~mm}$ insulation and without insulation. $\mathrm{k}_{\text {rain }}$ is 0.3 .

For a rain exposure coefficient of 0.3 there is a change in the development in $\mathrm{RH}$ in the non-insulated wall and the fully insulated wall. The wall without insulation has a declining trend below $80 \% \mathrm{RH}$ over four years whereas the insulated wall increases above $80 \% \mathrm{RH}$ and thus the $\mathrm{MC}$ will likely exceed the critical limit. Based on this information it is suggested that for this particular wall configuration, a rain exposure coefficient of 0.1 is the upper limit for acceptable long-term retrofit measures.

\section{Drying potential to the inside}

The retrofit measure in which there is a gap in the insulation would permit drying to both the inside and outside when a vapour barrier is not placed on the un-insulated portion of the wall (referred to as free wall in Figure 6). Whereas, if a vapour barrier is placed on the free wall the drying potential would be limited to only the outside. 


\section{SUBMITTED VERSION 1 - BEFORE PEER-REVIEW}

\section{MAJOR CHANGES WERE MADE TO THE FINAL VERSION OF THE PAPER}

After four years of simulation the $\mathrm{RH}$ and $\mathrm{MC}$ is equal to the retrofit measure with or without a vapour barrier on the free wall as shown in Figure 11.

a)

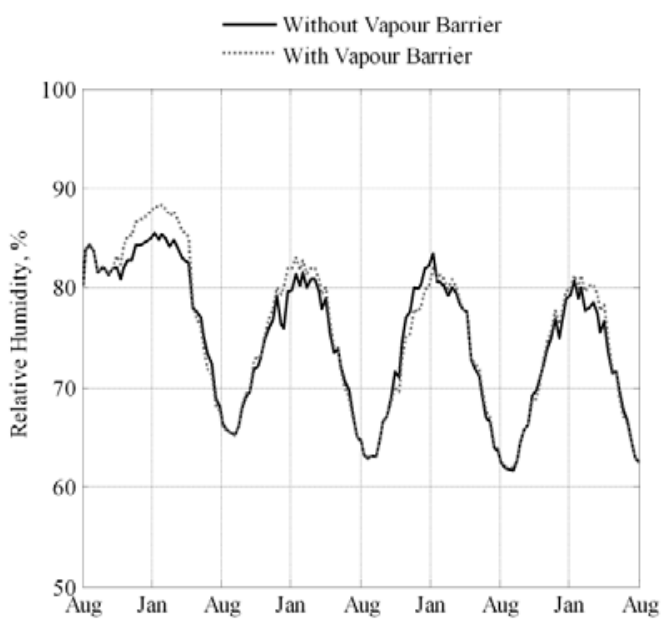

b)

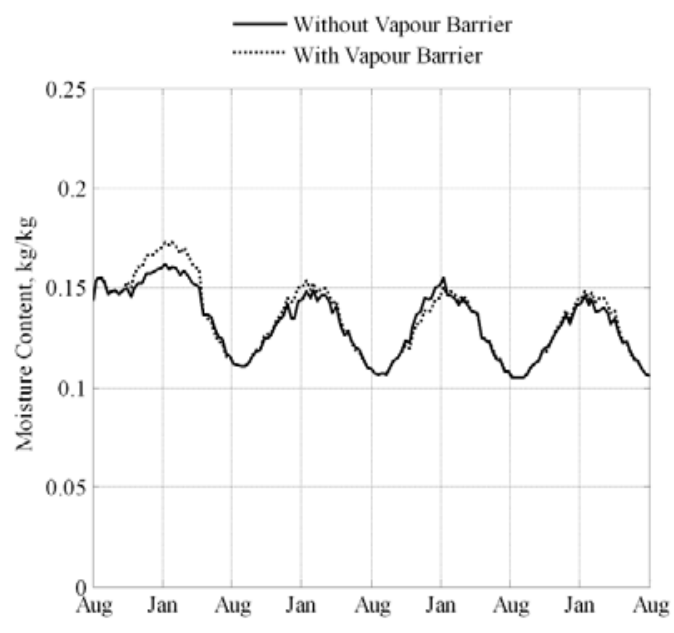

Figure 11. Indication of the drying potential through the free wall expressed by a) relative humidity, temperature and b) moisture content. Measure with $100 \mathrm{~mm}$ insulation, $200 \mathrm{~mm}$ gap and $\mathrm{k}_{\text {rain }}=0.1$.

\section{Mould growth in the gap}

As is evident in Figure 12 the RH at the interface between the brick masonry and insulation (see Figure 6) increases above the $80 \%$ for long periods of the year when insulation is applied to the interior of the wall assembly and without gaps at the base of the wall. However, in walls that have a gap in the insulation at the base of the wall on the interior, the same problem could arise, that is, prolonged periods of elevated RH may occur at the brick masonry-insulation interface. In Figure $12 \mathrm{~b}$ there is shown a rise in $\mathrm{RH}$ above $80 \%$ for a short period of time during the winter period where the temperature also is about $12^{\circ} \mathrm{C}$. The increase in $\mathrm{RH}$ is brought about due to the lower wall temperatures that occur when insulation is applied to the interior of the wall assembly. Applying $100 \mathrm{~mm}$ or $200 \mathrm{~mm}$ insulation implies small and less significant changes in temperature and $\mathrm{RH}$ at this interface. As compared to the un-insulated wall, the $\mathrm{RH}$ in this instance is about $20 \%-30 \%$ greater. The drying 


\section{SUBMITTED VERSION 1 - BEFORE PEER-REVIEW}

\section{MAJOR CHANGES WERE MADE TO THE FINAL VERSION OF THE PAPER}

potential thorugh the free wall is insignificant and again a rain exposure coefficient of 0.1 is the upper limit for this particular wall configuration.

a)

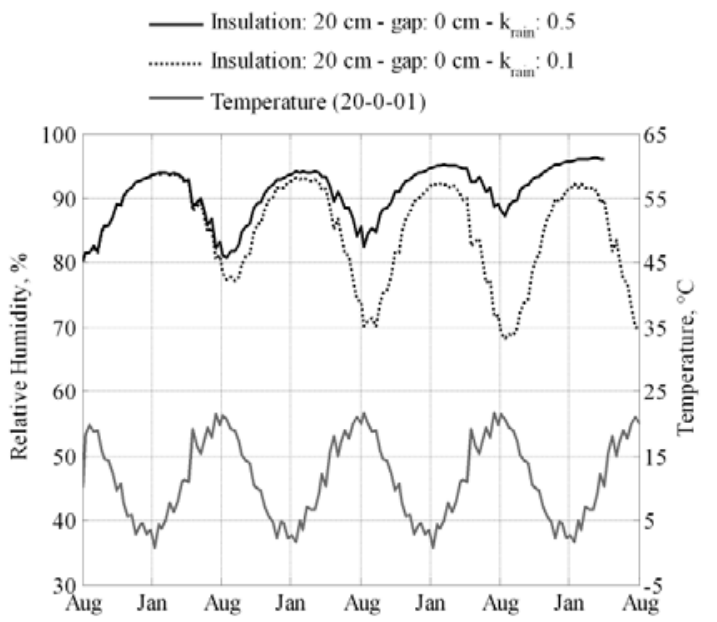

b)

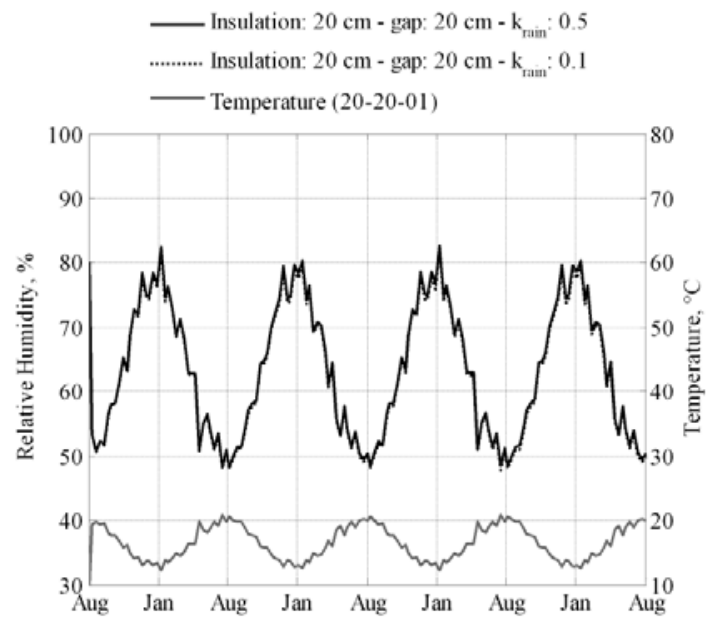

Figure 12. Temperature and relative humidity in the corner where the inside insulation stops $200 \mathrm{~mm}$ above the floor.

\section{DISCUSSION}

Many factors may influence the long-term hygrothermal performance of the wooden beam ends; for example, the actual material properties (as compared to assumed properties), climatic conditions and orientation of the wall. The result obtained in this paper represent those for one particular case in which insulation, of $100 \mathrm{~mm}$ or $200 \mathrm{~mm}$ thickness, has been installed on the interior of a brick masonry wall assembly; however this measure is considered to be valid for west-facing facades of buildings located in comparable cool and humid northern European climates. The results of the simulation that relate to thermal effects indicate a significant potential for energy saving when insulation is applied to the interior of the wall assembly. Referring to the coupling coefficient, it appears that a saving of 51-86\% in energy can be achieved depending on the measures chosen. Specifically, leaving a gap in the insulation necessarily reduces the thermal performance and in comparison to a fully insulated wall, performs 2-3 times better than a retrofit measure with a $200 \mathrm{~mm}$ gap in the insulation. An internal retrofitting can halve the heat loss compared with the original wall, even with a $200 \mathrm{~mm}$ un-insulated 


\section{SUBMITTED VERSION 1 - BEFORE PEER-REVIEW}

\section{MAJOR CHANGES WERE MADE TO THE FINAL VERSION OF THE PAPER}

gap in the insulation. This is in good agreement with previously studies of walls with wooden beam end that have insulation installed on the interior of the wall. Thus an un-insulated gap in the insulation will be a good retrofit measure when looking at the thermal performance of the structure. Still there is a risk of degradation of the wooden beam end due to the inside insulation. Therefore, both care and special case measures are required to make this big energy saving potential accessible.

The FMEA listed the potential failures, effects and causes for the different components in the wall assembly. Among the most critical effects was the collapse of the beam end which is a side effect of moisture penetration into the structure. In the FMEA a rating of the failures was not performed and therefore it can be discussed if focus should be put on the beam end or other failures. Other failures could lead to more maintenance than the beam end. The worst failure that can happen is that after 50 years the beam will deteriorate due to the applied inside insulation and thereby cause loss of human life. The use of FMEA in the development of retrofit measures clarifies the potential to identify failures and effects which then should be investigated using e.g. hygrothermal simulations. To obtain the full value of the FMEA process, a ranking of the failures should be performed but this can easily become a subjective ranking if it is based on expert knowledge. In the present case, applying the FMEA to the masonry wall with embedded wooden beams, was time consuming and little, if any, new knowledge in respect to the long-term performance of the wall assembly was obtained. When considering the suitability of specific retrofit measures, control of moisture within components of the wall assembly is the overriding issue and can roughly be divided into failures that arise due to the effects of condensation, freezethaw action, and water intrusion depending on the constituent materials of the respective wall components. Perhaps the use of 1D simulation to investigate the hygrothermal performance of the wall assembly would provide more useful information as that obtained from performing the FMEA.

The wind-driven rain has a large influence on the moisture performance of the wooden beam which is shown with by changing the rain exposure coefficient. A low value of wind-driven rain $\left(\mathrm{k}_{\mathrm{rain}}<0.1\right)$ indicates no moisture 


\section{SUBMITTED VERSION 1 - BEFORE PEER-REVIEW}

\section{MAJOR CHANGES WERE MADE TO THE FINAL VERSION OF THE PAPER}

problems in the beam end. A retrofit measure with installation of an inside insulation with a gap in the insulation could be durable at intermediate values $\left(\mathrm{k}_{\text {rain }}<0.3\right)$ extrapolated from the trends for low and high rain loads.

Earlier measurements of moisture content in wooden beam ends showed in general no moisture problems but the amount of wind-driven rain was not stated clearly in these investigations. Therefore it is difficult to validate the results in this paper with previously measured values. From Blocken and Carmeliet (2006) it is known that the catch ratio is highest in the top corners of buildings and lowest in the middle close to the ground. On the one hand it can be questioned if the low values of rain exposure coefficients are realistic and representative for the most critical beam end. On the other hand the rain amount depends significantly on the climate and location of the buildings. The wind driven rain applied using a test reference year does not account for extreme years that might occur every 20,30 or 50 years. This could be very important consideration if the trends in hygrothermal response of the wall assembly are at the critical limits for onset of mould growth or wood decay.

Comparing the retrofit measures with the reference measure gives clear indications on the performance of the retrofit measure. The reference measure has nonetheless existed for around 100 year and if the new retrofit measure performs equally well the long term-performance must be intact as it is assessed that the existing structure can last for another 100 years. It is seen that when installing insulation to the interior and with at gap at the base of the wall there is an insignificant change in the temperature, relative humidity and moisture content of the beam end as compared to the deviations occurring when insulation is installed over the entire wall.

The inside effects the drying to the inside which is all eliminated even for the measure implementing a gap at the base of the insulation. The effect of placing a vapour barrier or not on the free wall showed no changes in the relative humidity or moisture content in the beam end. Therefore, the lower relative humidity and moisture content at the beam end compared to the entire insulated wall is due to the extra heat loss through the gap. The minor increase in relative humidity when leaving a gap in the insulation compared to the reference measure shows that even a halved heat loss will be sufficient to heat up the beam end to secure the long-term durability. Applying inside insulation normally gives relative humidity above the critical level in the brick-insulation interface. This is also the case when applying the insulation all the way to the floor. If instead a gap is left in the 


\section{SUBMITTED VERSION 1 - BEFORE PEER-REVIEW}

\section{MAJOR CHANGES WERE MADE TO THE FINAL VERSION OF THE PAPER}

insulation towards the floor the corner between the insulation and existing inside wall perform much better than the fully insulated measure. The surface temperature stays above $10^{\circ} \mathrm{C}$ with an insulation gap and therefore is not critical for mould growth or condensation.

The proposed retrofit measures leaving a gap in the insulation could be a usable measure when looking at the modest increase in relative humidity and moisture content compared with the un-insulated wall. The question is how practicable the measure is leaving a gap in the insulation of $200 \mathrm{~mm}$. From an aesthetic point of view this measure can be questioned. One would probably not apply the inside insulation leaving a gap under the ceiling and towards the floor. The height of the gap is the same as the existing skirting which could be made so warm air could enter the gap and not perform insulation layer of air which then could lead to increases of relative humidity and moisture content for rain loads on the threshold for onset of mould growth or wood decay.

\section{CONCLUSION}

This paper presented a methodology for developing new retrofit measures using failure mode and effect analysis combined with hygrothermal simulations. The results from this study appear to indicate that significant energy savings can be achieved when applying insulation to the interior of a masonry walls. Nonetheless, the installation of insulation on the interior of the wall, in which wooden beams are incorporated, can lead to moisture problems at beam ends and ultimately in the worst case, deterioration of the beam end. A straightforward way of dealing with this problem is leaving a $200 \mathrm{~mm}$ gap in the insulation. The relative humidity and moisture content at the beam end would then be very much like that of the un-insulated structure. Based on these findings it is concluded that the new retrofit measure leaving a gap in the insulation will be an adequate retrofit measure. The hazards identification of applying inside insulation on masonry walls with wooden beam ends were investigated using failure mode and effect analysis (FMEA). Two measures were investigated; one fully insulated wall and one with a $200 \mathrm{~mm}$ un-insulated at the base of the wall. From the FMEA the effect of moisture entering the structure leading to deterioration of the beam end was assessed as the worst case failure and further analysed regarding the durability. The use of FMEA was very time consuming and the results 


\section{SUBMITTED VERSION 1 - BEFORE PEER-REVIEW}

\section{MAJOR CHANGES WERE MADE TO THE FINAL VERSION OF THE PAPER}

obtained from this analysis was not considered proportional to any new knowledge gained through the process. No ranking of the failures were performed which easily can be subjective evaluation. Therefore, it was concluded that the FMEA was not useful in the assessment of moisture durability of such wall assemblies. From an energy point of view the suggested retrofit measures can contribute to significant energy savings. Leaving an un-insulated part of the wall will still half the heat loss compared to the existing wall. This extra heat loss through the non-insulated wall part and beam end shows only a minor increase in the relative humidity and moisture content in the beam end. For low rain loads $\left(\mathrm{k}_{\text {rain }}=0.1\right)$ installation of insulation on the interior can be done over the entire wall, whereas for intermediate rain loads $\left(\mathrm{k}_{\text {rain }}=0.3\right)$ will be on the edge and a gap measure could be the measure to the moisture durability issue. Therefore, it is concluded that the measure with a gap will be durable retrofitting even though the drying through the gap has no influence on the moisture content in the beam end. From the simulation it is also concluded that the wind-driven rain has a great influence on the performance of the wooden beam end. The rain amount is crucial for the durability of the structure when applying inside insulation. The un-insulated wall part will not be exposed for mould growth as the part of the wall behind the insulation.

Finally it is concluded that the use of the retrofit measure cannot be placed in a Northern European context before performing further studies related to assessing the performance for different climate locations having different values of rain intensity.

\section{REFERENCES}

Blocken, B., Defraeye, T., Derome, D. and Carmeliet, J., 2009. High-Resolution CFD Simulations for Forced Convective Heat Transfer Coefficients at the Facade of a Low-Rise Building. Building and Environment, vol. 44, no. 12 , pp. 2396-2412. 


\section{SUBMITTED VERSION 1 - BEFORE PEER-REVIEW}

\section{MAJOR CHANGES WERE MADE TO THE FINAL VERSION OF THE PAPER}

Blocken, B. and Carmeliet, J., 2006. The Influence of the Wind-Blocking Effect by a Building on its WindDriven Rain Exposure. Journal of Wind Engineering \& Industrial Aerodynamics, vol. 94, no. 2, pp. 101-127 ISSN 01676105.

Blomberg, T., 2010. HEAT2: Simulation Program for Heat Transfer in Two Dimension.[Download] Available at: <http://www.buildingphysics.com/> [Accessed 10 January 2010].

Blomberg, T., 1996. HEAT CONDUCTION IN TWO AND THREE DIMENSIONS Computer Modelling of Building Physics Applications. PhD, Report TVBH-1008. Lund University, Department of Building Physics, Sweden.

Christensen, G. and Bunch-Nielsen, T., 2009. Indvendig Efterisolering Af Aldre Ydermure (BYG-ERFA Erfaringsblad (31) 0910 29). Ballerup, Denmark: BYG-ERFA.

Derluyn, H., Janssen, H. and Carmeliet, J., 2011. Influence of the Nature of Interfaces on the Capillary Transport in Layered Materials. Construction and Building Materials, vol. 25, no. 9, pp. 3685-3693 ISSN 09500618.

EN ISO, 2007. EN ISO 6946:2007 - Building components and building elements - Thermal resistance and thermal transmittance - Calculation method (ISO 6946:2007).

Engelmark, J., 1983. Københavns Etageboligbyggeri 1850-1900. En Byggeteknisk Undersøgelse. Hørsholm: Danish Building Research Institute.

EU Directive 2010/31/EU of the European Parliament and of the Council of 19 May 2010 on the energy performance of buildings (recast), Official Journal of the European Union, 18/06/2010. 19 May 2010 ed. EU of the European Parliament.

Feist, W., 2005. Faktor 4 Auch Bei Sensiblen Altbauten: Passivhauskomponenten + Innendämmung. Darmstadt: Passivhaus Institut. 


\section{SUBMITTED VERSION 1 - BEFORE PEER-REVIEW}

\section{MAJOR CHANGES WERE MADE TO THE FINAL VERSION OF THE PAPER}

Grunewald, J., 1997. Diffusiver Und Konvektiver Stoff- Und Energietransport in Kapillarporösen Baustoffen. PhD. Dresden University of Technology, Germany.

Häupl, P., 2010. Innendämmung von Aussenbauteilen. In: Bauphysik KalenderBerlin, Germany: Ernst \& Sohn. pp. 147-186. ISBN 978-3-433-02938-1.

Häupl, P., Fechner, H. and Petzold, H., 2004. Interior Retrofit of Masonry Wall to Reduce Energy and Eliminate Moisture Damage: Comparison of Modeling and Field Performance. In: Thermal Performance of the Exterior Envelopes of Whole Buildings IX. Clearwater Beach, Florida, 5-10 December. Atlanta: ASHRAE.

Häupl, P., Fechner, H. and Ruisinger, U., 2006. Moisture atlas for building envelopes. In: Research in Building Physics: Proceedings of the 3nd International Conference on Building Physics. Montreal, Canada, 27-31 August. London: Taylor and Francis.

Häupl, P., Jurk, H. and Petzold, H. 2003. Inside thermal insulation for historical facades. In: Research in Building Physics: Proceedings of the 2nd International Conference on Building Physics. Leuven, Belgium, 1418 September. Lisse: Swets and Zeitlinger.

Janssen, H., Blocken, B., Roels, S. and Carmeliet, J., 2007. Wind-Driven Rain as a Boundary Condition for HAM Simulations: Analysis of Simplified Modelling Approaches. Building and Environment, vol. 42, no. 4, pp. $1555-1567$.

Krebs, H.J. and Collet, P.F., 1981. Indvendig Efterisolering. Indmurede Bjoelkeenders Fugt- Og

Temperaturforhold i Etagekryds. 1.th ed. Tåstrup: Danish Technological Institute. ISBN 9788775111558; 8775111551.

Mao, Q., Fazio, P. and Rao, J., 2011. A Limit State Design (LSD) Approach for Comparing Relative Drying Performance of Wood-Frame Envelope Systems with Full-Scale Lab Testing. Building and Environment, vol. 46, no. 3, pp. 797-806. ISSN 03601323; 1873684x. 


\section{SUBMITTED VERSION 1 - BEFORE PEER-REVIEW}

\section{MAJOR CHANGES WERE MADE TO THE FINAL VERSION OF THE PAPER}

McDermott, R.E., Mikulak, R.J. and Beauregard, M.R., 2009. The Basics of FMEA. 2nd ed. New York:

Productivity Press.

Morelli, M., Scheffler, G., NIELSEN, T.R. and Svendsen, S., 2010. Internal Insulation of Masonry Walls with Wooden Floor Beams in Northern Humid Climate. In: Thermal Performance of the Exterior Envelopes of Whole Buildings XI. Clearwater Beach, Florida, 5-9 December. Atlanta: ASHRAE.

Munch-Andersen, J., 2008. SBi-Anvisning 221. Efterisolering Af Etageboliger. Hørsholm: Aalborg University:

Danish Building Research Institute.

Nicolai, A., Grunewald, J. and Fechner, H., 2010. DELPHIN: Simulation Program for Coupled Heat, Air, Moisture, Salt and VOC Transport. [Download] Available at: <www.bauklimatik-dresden.de/delphin>, [Accessed 13 January 2010].

Rasmussen, T.V., 2010. Post-Insulation of Existing Buildings Constructed between 1850 and 1920. In: Thermal Performance of the Exterior Envelopes of Whole Buildings XI. Clearwater Beach, Florida, 5-9 December. Atlanta: ASHRAE.

Sedlbauer, K., 2002. Prediction of Mould Growth by Hygrothermal Calculation. Journal of Building Physics, vol. 25 , no. 4 , pp. 321-336.

Sharples, S., 1984. Full-Scale Measurements of Convective Energy Losses from Exterior Building Surfaces. Building and Environment, vol. 19, no. 1, pp. 31-39.

Stamatis, D.H., 2003. Failure Mode and Effect Analysis: FMEA from Theory to Execution. 2nd ed. Milwaukee, US: ASQ Press. 


\section{SUBMITTED VERSION 1 - BEFORE PEER-REVIEW}

\section{MAJOR CHANGES WERE MADE TO THE FINAL VERSION OF THE PAPER}

Stopp, H. and P. Strangfeld., 2006. Hygrothermics of wooden beam ends in envelope parts of buildings. In:

Research in Building Physics: Proceedings of the 3nd International Conference on Building Physics. Montreal, Canada, 27-31 August. London: Taylor and Francis.

Talon, A., 2006. Évaluation Des Scénarii De Dégradation Des Produits De Construction.PhD. Centre Scientifique et Technique du Bâtiment - Département Développement Durable - Division Environnement, Produits et Ouvrages Durables Et au Laboratoire Génie Civil, Grenoble, France.

Talon, A., Chevalier, J. and Hans, J., 2006. Failure Modes Effects and Criticality Analysis Research for and Application to the Building Domain. CIB Report: Publication 310. International Council for Research and Innovation in Building and Construction (CIB), Rotterdam, the Netherlands. ISBN: 90-6363-052-2.

Tommerup, H. and Svendsen, S., 2006. Energy Savings in Danish Residential Building Stock. Energy and Buildings, vol. 38, no. 6, pp. 618-626. DOI 10.1016/j.enbuild.2005.08.017.

Viitanen, H., Vinha, J., Salminen, K., Ojanen, T., Peuhkuri, R., Paajanen, L. and Lähdesmäki, K., 2010. Moisture and Bio-Deterioration Risk of Building Materials and Structures. Journal of Building Physics, vol. 33, no. 3, pp. 201-224.

Wittchen, K.B., 2009. Potentielle Energibesparelser i Det Eksisterende Byggeri. Hørsholm: Danish Building Research Institute. 